(The 3rd ICBS-2013)

\title{
NEW REPORT ON THE DISTRIBUTION OF RARE BIRD SPECIES IN TAHURA RADEN SOERJO, EAST
}

\author{
Heru Cahyono, Haris Eka Pramudhita, Windri Hermadiyanti \\ Malang Eyes Lapwing (MEL) Bird Study Group, Biology Department, \\ Faculty of Mathematics and Science, State University of Malang, Jl. Semarang 5, Malang, Indonesia 65145. Heru \\ Cahyono: hc_garuda@yahoo.com
}

\begin{abstract}
The latest information about the distribution of a less-recorded Java-dwelling bird species found in Tahura Raden Soerjo (East Java) is noteworthy additional information in the field of ornithology. Observations were conducted in the Cangar tourism site, along the main road linking Pacet and Batu, as well as in the northern area of Tahura Raden Soerjo, which includes the hiking trails of the Welirang-Arjuno mountains. The birds with minimum records are the Hill Myna (Gracula religiosa), Thick-billed Flowerpecker (Dicaeum agile), Yellow-vented Flowerpecker (Dicaeum chryssorheum), Sunda Thrush (Zoothera andromedae), Narcissus Flycatcher (Ficedula narcissina), Brown Wood-owl (Strix leptogrammica), Oriental Bay-owl (Phodilus badius), and Rhinoceros Hornbill (Buceros rhinoceros). Several findings are supported with detailed documentations and direct observation data that can be accounted for. This information denotes that Tahura Raden Soerjo is a potential hotspot to be preserved for the sake of the rare bird species and the other biodiversity.
\end{abstract}

Keywords: Tahura Raden Soerjo, sighting reports, distribution, observation

\section{INTRODUCTION}

The number of published information on the bird species list in Tahura Raden Soerjo has been meager, given the fact that the area covers more than $27,868.30 \mathrm{Ha}$ (UPT TRS, 2011). That coverage has been proven to possess valuable potential, the data of which was recorded and compiled during the FOBI Expedition (Foto Biodiversitas Indonesia, 2012). This paper will discuss the sightings of several rare birds in Tahura Raden Soerjo that are essential to the field of ornithology, be it about updated distribution areas, new sightings, or conservation status.

\section{MATERIALS AND METHODS}

The information on the sighting of the long-lost Hill Myna, which was reported on 2 January 2010 in the northern part of Tahura Raden Soerjo, has been included in our list of lessrecorded bird species, while we have also been working on the data collection of other birds until this year. Observations were conducted in the Cangar tourism site, particularly by the main road linking Pacet and Batu, as well as the northern part of Tahura Raden Soerjo, which covers the main hiking trail of the Welirang-Arjuno mountains. Observations took place at different times, and the species identification followed the guide from Burung-burung di Sumatera, Jawa, Bali dan Kalimantan (MacKinnon et al., 2000).

\section{RESULTS AND DISCUSSION}

1. Hill Myna Gracula religiosa (Linnaeus, 1758)

The first sighting of this Least Concern bird species (BirdLife, 2001) was in 1996, near Kakek Bodo waterfall, Prigen, Pasuruan, which is still within the area of the state-owned 
forest, abuts on the northern part of Tahura Raden Soerjo, 878 meters above sea level. This species was insufficiently observed, and only three individuals at most were seen. On being observed, they were perching on a tall branch close to the waterfall ( $07^{\circ} 42^{\prime} 01.3^{\prime \prime} \mathrm{S} 112^{\circ} 37^{\prime}$ 30.2" E) 878 meters above sea level. During 1996-1999 this species was never been spotted to be more than two individuals. The last sighting occurred on 2 January 2010, when one individual flew above Swietenia macrophylla and Mesopsis eminii (van Steenis, 2006) trees around Pok Limas ( $\left.07^{0} 42^{\prime} 10.9^{\prime \prime} \mathrm{S} 112^{\circ} 37^{\prime} 29.7^{\prime \prime} \mathrm{E}\right)$, headed up towards the northern part of Tahura Raden Soerjo. The information on the distribution of the Hill Myna in Tahura Raden Soerjo is supported by the area's data (2005), which unfortunately does not mention the exact location. This species used to be abundant across the forests of Java, but its number has been rapidly decreasing as the result of hunting and habitat loss (MacKinnon et al., 2000). The latest information mentions that this species still can be found in Alas Purwo National Park (Grantham, 2000), and Baluran National Park in 2005-2011 (Winnasis et al., 2011).

\section{Thick-billed Flowerpecker Dicaeum agile (Tickell, 1833)}

Five reported sightings of this Least Concern (BirdLife, 2001) species came from different locations and altitudes. The first sighting took place at the hiking trail of the WelirangArjuno mountains, 1300 meters above sea level, on 9 August 2009; one individual was seen in an open forest by a hill slope. In the second, third, and fourth sightings around the Pine Trees state-owned production forest, Prigen ( $07^{0} 41^{\prime}$ 58.4" S $112^{\circ} 37^{\prime} 39.6$ " E) 899 meters above sea level, on 4 April 2013, 27 April 2013, and 8 May 2013, 1-3 individuals were found while calling and eating the white fruits of Saurauiaceae family trees (van Steenis, 2006). The fifth sighting was quite far-off from the previous sightings, approximately $50 \mathrm{~km}$ westward. The location is still within the area of Tahura Raden Soerjo, in the part administratively belonging to Mojokerto, just before Gajahmungkur hill (742.418’ S 112³1.753’ E), 1140 meters above sea level, on 17 May 2013. The lone bird was perching upon a dry branch and calling, before it flew into the dense foliage of Trema orientalis and Gmelina arborea (van Steenis, 2006). Information on the sighting of Thick-billed Flowerpecker in Java is still inadequate with minimum updates from the field, but it has been reported to be populating Ujung Kulon National Park, Meru Betiri National Park, and Alas Purwo National Park (MacKinnon et al., 2000). These five sighting reports at different spots had refined the documentation and distribution record. The area from Trawas to the location of the fifth sighting covers an area as wide as $40 \mathrm{~km}$, and from Trawas-Prigen as wide as $8 \mathrm{~km}$.

\section{Yellow-vented Flowerpecker Dicaeum chrysorrheum (Temminck, 1829)}

This species was first spotted on a sunny day on 26 August 2009, somewhere along the hiking trail by the foot of the Welirang-Arjuno mountains, 1300 meters above sea level. One individual was seen foraging in a short tree by the bushes, six meters away from the observers. The forest was of average density, close to an open forest and hill slopes. Information and documentation of the sightings of this species has not been obtained yet because of infrequent observation. In Java, its sighting is also very limited; the last reported sightings were in Ranca Danau Natural Reserve and Meru Betiri National Park (MacKinnon et al., 2000), thus the 
sighting in Tahura Raden Soerjo had refined the distribution record of this vulnerable (BirdLife, 2001) bird species.

4. Sunda Thrush Zoothera andromedae (Temminck, 1826)

The first sighting of this Least Concern (BirdLife, 2001) species was on 27 November 2011 at Lemahbang ( $\left.7^{\circ} 42^{\prime} 58.10^{\prime \prime} \mathrm{S} 112^{\circ} 31^{\prime} 33.60^{\prime \prime} \mathrm{E}\right), 1250$ meters above sea level, right after hard rain had ceased. One immature individual were seen flying low crossing the road at 4:29 p.m. The bird was about to forage in mulch, before flying away into the shrubs. The next encounter with this species was in December 2011 around Watu Ondo, next to the river where one individual was seen at 07:10 a.m. The third sighting was in Lemahbang $\left(7^{\circ} 43^{\prime}\right.$ 18.03" S 112 31' 37.65" E) on 4 April 2012 during the FOBI Expedition (1-7 April 2012). One adult was spotted at dusk (around 5:28 p.m.), while foraging by the road and flying across several times.

The fourth encounter was on 1 October 2012 in Watu Ondo $\left(7^{\circ} 44^{\prime} 4.00^{\prime \prime} \mathrm{S} 112^{\circ} 31^{\prime}\right.$ 43.40" E) 1357 meters above sea level, at 07:35 a.m. One immature individual was seen foraging in mulch, five meters away from the observers. It did not seem to be disturbed by the presence of humans or motor vehicles; the weather was bright and observation lasted for 20 minutes. Initial records in Java were limited to Gede Pangrango and Halimun Salak National Parks (MacKinnon et al., 2000). This first ever sighting of the Sunda Thrush in East Java has rectified its distribution data, along with the other reports from Merapi National Park on 21 April 2012 (Ahmad Zulfikar Abdullah, pers. comm., 2012) and from Tlogo Nirmolo on 26 August 2012 (Prajawan Kusuma Wardhana, pers. comm., 2012).

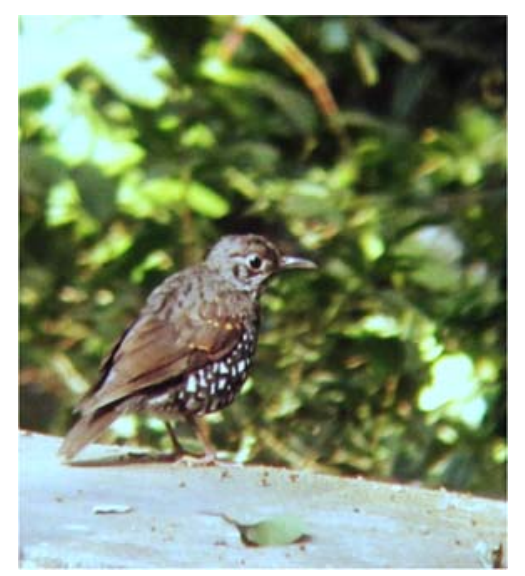

Figure 1. Sunda Thrush (Zoothera andromedae), in Tahura Raden Soerjo on 1 October 2012. Photo by Heru Cahyono.

5. Narcissus Flycatcher Ficedula narcissina (Temminck, 1835)

Sighting information of this Least Concern (BirdLife, 2001) bird species was reported in the migrating season, 3 February 2013 in Sendi, Mojokerto (7० 42' 8.00" S $112^{\circ} 31^{\prime} 49.20^{\prime \prime}$ E), 1067 meters above sea level. One adult individual was perching on a Trema orientalis tree; observers were able to watch from 15 meters away for 10-15 minutes before the bird finally flew away into the forest. This is just the second-reported sighting of this species in Java, for previously its distribution was known to be limited to Borneo (Sukmantoro et al., 2007). 


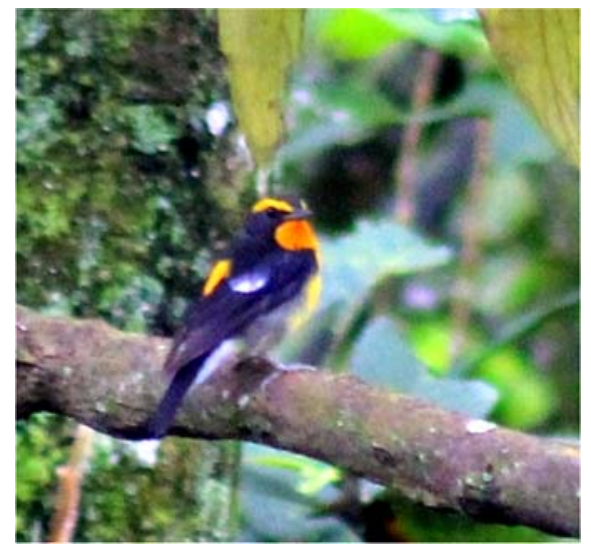

Figure 2. Narcissus Flycatcher (Ficedula narcissina), in Tahura Raden Soerjo on 3 February 2012. Photo by Heru Cahyono.

Prior to the sighting in Tahura Raden Soerjo, Yann Muzika and Hery Kusumanegara reported a sighting in ljen on 12 March 2012 (Muzika, 2012), and a third sighting followed on 5 March 2013 in a coffee plantation in Situbondo (Arif Rachman pers.comm., 2013).

6. Brown Wood-owl Strix leptogrammica (Temminck, 1831)

A sighting of this bird was reported on 26 November 2011 in the jogging track of Cangar ( $\left.7^{\circ} 44^{\prime} 35.35^{\prime \prime} \mathrm{S} 112^{\circ} 32^{\prime} 5.00^{\prime \prime} \mathrm{E}\right) 1733$ meters above sea level. At the same time, the third Oriental Bay-owl was also spotted at 4 p.m. One individual of Brown Wood-owl was perching in a tall branch about 14 meters above the ground, 20 meters away from the observers. The bird flew away just before we could take its picture.

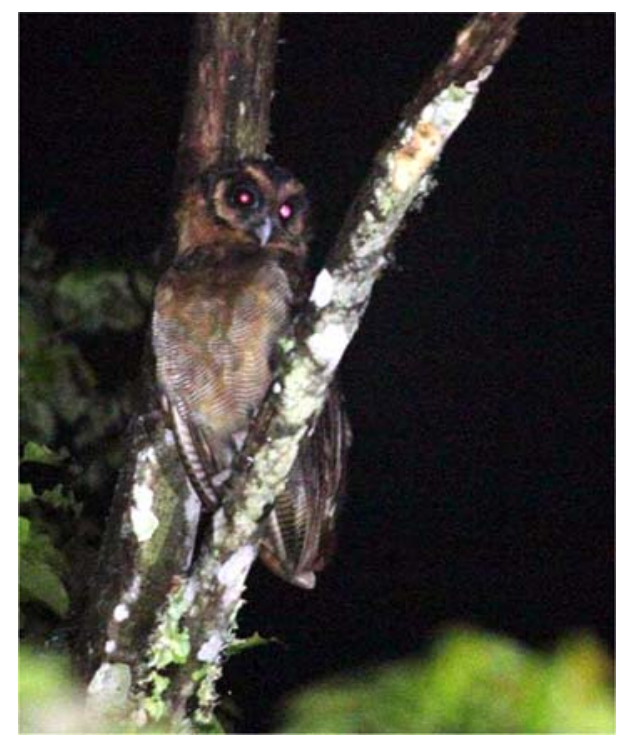

Figure 3. Brown Wood-Owl, at Watu Ondo, Tahura Raden Soerjo on 1 April 2012. Photo by Khaleb Yordan.

In the FOBI Expedition on 1 April 2012, a Brown Wood-owl was seen again at 10 p.m. near Watu Ondo bridge ( $\left.7^{\circ} 44^{\prime} 10.00^{\prime \prime} \mathrm{S} 112^{\circ} 31^{\prime} 48.40^{\prime \prime} \mathrm{E}\right)$ after it had rained, when it was perching on a dead branch about 10 meters above the ground, about 10 meters away from the observers. This encounter was well-documented before the bird disappeared into the 
dense foliage of Engelhardia spicata (van Steenis, 2006). This bird had been insufficiently observed (MacKinnon et al., 2000). Previous visual and auditory encounter reports came from Cibodas in 1983 and 1984 (Andrew, 1985) and from the pristine forest of Merbabu Mountain on 24 April 2013 at 10:45 a.m., 2040 meters above sea level (Kasih Putri Handayani, press.comm., 2013).

The sighting reports from Tahura Raden Soerjo and Merbabu Mountain have augmented the information on the distribution of this Least Concern (BirdLife, 2001) species.

\section{Oriental Bay-owl Phodilus badius (Horsfield, 1821)}

On 19 November 2011, a pair of Oriental Bay-owls was spotted for the first time in the jogging track of Cangar ( $\left.7^{\circ} 44^{\prime} 35.35^{\prime \prime} \mathrm{S} 112^{\circ} 32^{\prime} 5.00^{\prime \prime} \mathrm{E}\right) 1710$ meters above sea level, at 11:00 a.m. when they were perching on a branch of a Acronychia trifoliata tree (van Steenis, 2006), 6-7 meters above the ground by a ravine, 10-12 meters away from observers. The third and fourth sightings of this Least Concern (BirdLife, 2001) species occurred in the same location; the fourth was reported by a participant of the FOBI Expedition. Erstwhile reports came from Baluran and Gede Pangrango National Parks (MacKinnon et al., 2000), followed by others from Ungaran Mountain (Baskoro, 2009), Carita Wildlife Reserve (Khaleb Yordan, pers. comm., 2013), and Raung Mountain, Banyuwangi, on 2 August 2012.

These reports, including the ones we got from Tahura Raden Soerjo and Raung Mountain, denote that the distribution of the Oriental Bay-owl disperses in several pristine forests. However, this has not been well-recorded because of the scant observers who explore it.

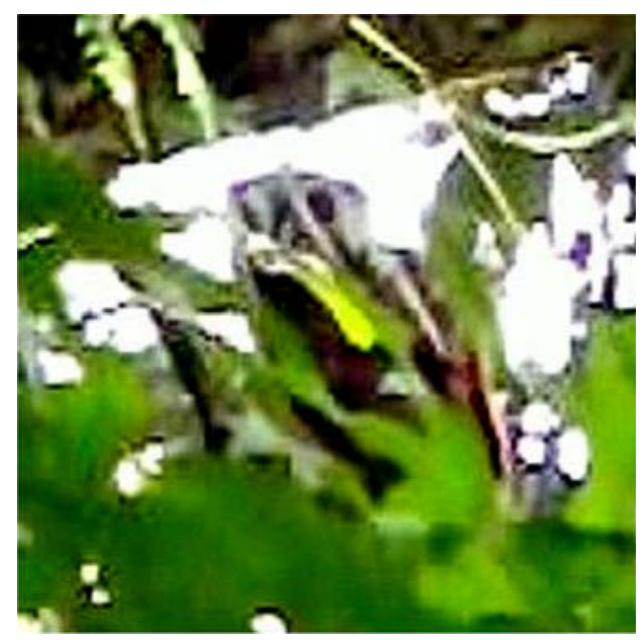

Figure 4. Oriental Bay-owl in Cangar, Tahura Raden Soerjo on 19 November 2011. Photo by Heru Cahyono.

8. Rhinoceros hornbill Buceros rhinoceros (Linnaeus, 1758)

An individual of this species was seen on 17 May 2013 at 11:00 a.m. on a cloudy day in Tahura Raden Soerjo, flying across the forest and the road around Sendi, Mojokerto ( $7^{\circ} 42^{\prime}$ 8.00" $\left.S 112^{\circ} 31^{\prime} 49.20^{\prime \prime} E\right), 1067$ meters above sea level. This encounter, and the previous ones by the rangers, support the distribution data of this Near Threatened (BirdLife, 2001) species, but the absence of documentation requires us to conduct more specific observation. According to the former records in Java, the Rhinoceros Hornbill can be found in Ujung Kulon National Park (Peucang Island) and Halimun-Salak National Park (Boas Emmanuel, 
pers. comm., 2013), Baluran National Park (Winnasis et al., 2011), Meru Betiri National Park and Alas Purwo National Park (Muzika, 2012), and the most recent report came from coffee plantations in Kayumas, Situbondo on 26 June 2013 (Arif Rachman pers. comm., 2013).

Related photo and video documentations can be downloaded from www.ibc.lynxeds.com and www.fobi.web.id.

\section{ACKNOWLEDGMENT}

We would like to thank Ms. Dwi Listyorini, Mr. Karyadi Baskoro, and other fellow birdwatchers who have contributed to the publication of this paper: Imam Taufiqqurahman, Toni Artaka, Ahmad Zulfikar Abdullah, Prajawan Kusuma Wardhana, Winda Afafa, Lya Vita Verdana, Mona Pirih, Khaleb Yordan, Boas Emmanuel, Kasih Putri Handayani, Arif Rachman, Sidiq Pambudi, Riri Wiyanti Retnaningtyas, Arif Budiawan, Bayu Hendra Prakosa, Aulia el Rahman Arif, Eko Wahyu, Arief Rahmatulloh, Adityas Arifianto, and Swasti Prawidya Mukti.

\section{REFERENCES}

UPT Tahura Raden Soerjo, 2011. Profil Tahura Raden Soerjo. Dinas Kehutanan Pemerintah Provinsi Jawa Timur.

Foto Biodiversitas Indonesia, 2012. Biodiversitas Indonesia (Bhinneka Flora Fauna Nusantara) www.fobi.web.id edisi Ekspedisi FOBI vol. 02 no. 02/2012.

MacKinnon, J., K. Phillipps, and B. van Balen. 2000. Burung-burung di Sumatera, Jawa,

Bali dan Kalimantan. Pustlitbang Biologi LIPI and Birdlife International Indonesia

Programme, Cibinong.

BirdLife International. 2001. Threatened Birds of Asia-the BirdLife International Red Data Book. BirdLife International, Cambridge.

van Steenis, C. G. G. J. 2006. Flora pegunungan Jawa. Pusat Penelitian Biologi-LIPI, Bogor. Grantham, M.J. 2000. Birds of Alas Purwo National Park, East Java. Kukila vol.11:97-121. Winnasis, S. Sutadi, A. Toha, and R. Noske. 2011. Birds of Baluran National Park. Direktorat Kawasan Konservasi dan Bina Hutan lindung.

Sukmantoro, W., M. Irham, W. Novarino, F. Hasudungan, N. Kemp, and M. Muchtar. 2007.

Daftar Burung Indonesia (Checklist of Indonesian Birds) No. 2. Indonesian Ornithologist's Union, Bogor.

Muzika, Y. 2012. Birding East Java. Accessed from: www.burungnusantara.com

Andrew, P. 1985. An annotated Checklist of the Birds of the Cibodas-Gunung Gede Nature Reserve. Kukila 2(1): 10-27.

Baskoro. 2009. Species Factsheet: Phodilus badius. www.fobi.co.web.id accessed on 7/6/ 2013

del Hoyo, J., A. Elliott, and J. Sargatal. 1999. Handbook of the birds of the World. Vol. 5. (Barn-owls to Hummingbirds). Lynx edicions, Barcelona.

UPT Tahura Raden Soerjo. 2005. Potensi Flora Fauna Tahura Raden Soerjo. Dinas Kehutanan Pemerintah Provinsi Jawa Timur. (unpublished). 